University of Nebraska - Lincoln

DigitalCommons@University of Nebraska - Lincoln

University of Nebraska Press -- Sample Books

and Chapters

University of Nebraska Press

2012

Positive Pollutions and Cultural Toxins

John Blair Gamber

Follow this and additional works at: https://digitalcommons.unl.edu/unpresssamples

Part of the Arts and Humanities Commons

Gamber, John Blair, "Positive Pollutions and Cultural Toxins" (2012). University of Nebraska Press -Sample Books and Chapters. 122.

https://digitalcommons.unl.edu/unpresssamples/122

This Article is brought to you for free and open access by the University of Nebraska Press at DigitalCommons@University of Nebraska - Lincoln. It has been accepted for inclusion in University of Nebraska Press -- Sample Books and Chapters by an authorized administrator of DigitalCommons@University of Nebraska - Lincoln. 
POSITIVE POLLUTIONS AND

\section{CULTURAL TOXINS}




\section{POSTWESTERN HORIZONS}

General Editor

William R. Handley

University of Southern California

Series Editors

José Aranda

Rice University

Melody Graulich

Utah State University

Thomas King

University of Guelph

Rachel Lee

University of California, Los Angeles

Nathaniel Lewis

Saint Michael's College

Stephen Tatum

University of Utah 


\section{POSITIVE POLLUTIONS AND CULTURAL}

TOXINS WASTE AND CONTAMINATION

IN CONTEMPORARY U.S. ETHNIC

LITERATURES JOHN BLAIR GAMBER

University of Nebraska Press | Lincoln and London 
(C) 2012 by the Board of Regents of the University of Nebraska

Some materials from the introduction reprinted from Survivance: Narratives of Native Voices, edited by Gerald Vizenor by permission of the University of Nebraska Press. (C) 2008 by the Board of Regents of the University of Nebraska. A version of chapter 5 originally appeared in PMLA I22, no. I (January 2007): I79-93.

All rights reserved Manufactured in the United States of America

())

Library of Congress Cataloging-in-Publication Data

Gamber, John Blair.

Positive pollutions and cultural toxins: waste and contamination in contemporary U.S. ethnic literatures / John Blair Gamber.

p. cm.-(Postwestern Horizons series)

Includes bibliographical references and index.

ISBN 978-0-8032-3046-0 (cloth: alk. paper)

I. American fiction-2Ist century-History and criticism.

2. American fiction-Minority authors-History and criticism.

3. Pollution in literature.

I. Title

PS374.P625G36 2012

810.9'3556-dc23 2012009223

Set in Scala by Kim Essman.

Designed by Ashley Muehlbauer. 


\section{CONTENTS}

Acknowledgments vii

Introduction I

1. "FAILING ECONOMIES AND TORTURED ECOLOGIES"

Octavia Butler's Parable of the Sower and Parable of the Talents 25

2. TOXIC METROPOLIS

Alejandro Morales's The Rag Doll Plagues 57

3. RIDDING THE WORLD OF WASTE

Louise Erdrich's The Antelope Wife 9I

4. "AN EERIE LIQUID ELASTICITY"

Karen Tei Yamashita's Tropic of Orange I2O

5. "OUTCASTS AND DREAMERS IN THE CITIES"

Gerald Vizenor's Dead Voices I55

Epilogue $\quad$ I83

Notes 187

Works Cited 213

Index 23I 


\section{ACKNOWLEDGMENTS}

The completion of this manuscript has not been an individual effort or accomplishment. There are a number of people whom I must acknowledge for their assistance and support and without whom this would not have been possible. I want to specifically thank and acknowledge:

My friends and colleagues at University of California, Santa Barbara, whose good humor and comradeship made my experiences infinitely better than they would have been without them. You know who you are.

My friends from the College of William and Mary: Elizabeth Barnes, Jack Martin, Colleen Kennedy, Anne Charity Hudley, Phillip Merritt, Will Hausman, Sarah Stafford, and Greg Hancock, for dealing me in. I don't know what I would have done without your kindness and warm welcome. I miss you all.

My sister Jennifer Rockwell, to whom I owe my life.

My brother Michael Petersen, for always being there.

My dissertation committee cochairs Professor Stephanie LeMenager, for her tireless effort and amazing responsiveness and support, and Professor Carl Gutiérrez-Jones, for all his help throughout my career, guiding this project from its inception to its completion; my committee members Professor Cheryll Glotfelty, whose insightful analysis and attention to detail has been invaluable, and Professor Shirley Geok-lin Lim, for her exceptional and unflagging professional guidance and mentorship.

And finally Mr. E. Friend, for his unwavering assistance during the composition of this piece.

I have presented versions of these chapters at conferences around the United States, Canada, and Taiwan. I am deeply appreciative of the feedback I have received at those gatherings. I would also like to acknowledge the William and Mary Faculty Summer Research Grant.

Any errors, oversights, or omissions are mine alone. 
POSITIVE POLLUTIONS AND

\section{CULTURAL TOXINS}




\section{INTRODUCTION}

Go against nature, It's part of nature, too.

LOVE AND ROCKETS, "No New Tale to Tell"

I love trash!

OSCAR THE GROUCH

Positive Pollutions and Cultural Toxins begins with the simple assumption that people are natural. I'm not the first person to suggest such a thing, as the Love and Rockets quote I use here as an epigraph indicates; but I hope this book will push some people's ideas about what is and is not, what can or cannot be considered "natural" in some new directions. Plants and trees are natural, of course. The flowers and the birds are natural. Apes and dolphins. Maggots. Viruses. People. Cities are natural. And traffic. And garbage. So are sewage and toxic waste. Human beings (Homo sapiens) are a biological species of the earth. We have evolved within a matrix (or rather, within infinite matrices) of forces, coevolved with innumerable (or at least innumerated) species, and continue to exist within biological, geological, physical, and ecological systems. Like other species, we are socialized. Like many other species, we construct dwellings for ourselves. Like some other species, we use tools. We are born, we breathe, we eat, we expel, we die. We're animals. We're natural. Moreover, as I hope to demonstrate, the impulse to distinguish humans from other life on the planet is dangerous to all life. As Cary Wolfe demonstrates, "Debates in the humanities and social sciences between well-intentioned critics of racism, (hetero)sexism, classism, and all other -isms that are the stock-in-trade of cultural studies almost always 
remain locked within an unexamined framework of speciesism" (I). Positive Pollutions and Cultural Toxins works to rearticulate this unexamined framework within comparative ethnic literary studies in particular.

Since Carolyn Merchant's The Death of Nature, a number of critics and theorists have described the end, destruction, or elimination of nature as a nonhuman collectivity or a human construct. ${ }^{1}$ Merchant points to the I6oos in Europe as the period during which "Western culture became increasingly mechanized" and "the female earth and virgin earth spirit were subdued by the machine" (2). She seeks to identify "the developments that resulted in the death of nature as a living being and the accelerating exploitation of both human and natural resources in the name of culture and progress" during the scientific revolution (xxi-xxii). For Merchant, the death of nature marks a break in especially European conceptions of the other-than-human as a living, indispensable, feminine force. In separating these vitalities from the "real world" of science and mechanisms, European societies came to devalue the other-than-human and the feminine, marking both as things to be conquered (or that had already been conquered). ${ }^{2}$ By contrast, Bill McKibbin's The End of Nature confronts humanity's growth into a global force on everything on the planet. In his updated introduction to this critically important text, he writes, "We are no longer able to think of ourselves as a species tossed about by larger forces-now we are those larger forces. Hurricanes and thunderstorms and tornadoes become not acts of God but acts of man. That is what I meant by the "end of nature" (xviii). ${ }^{3}$

Positive Pollutions and Cultural Toxins is not meant to signal the death of nature but rather its expansion. Each of the novels it studies challenges the distinction of the natural from the human by illustrating the permeable and permeated and the interrelated and interconnected realities of all species and ecologies. This text attempts to show that there is nothing, truly nothing, that is not natural (or that is unnatural). Some will argue that in expanding nature to encompass everything, I am in fact emptying it of significance, and there may be some merit to such an argument. However, because the word-concept nature continues to circulate so freely and abundantly, it behooves us to understand what we think we mean when we wield the term and in what ways our concepts of the natural fail upon further review. Wolfe points out that many popu- 
lar as well as scholarly venues "have made standard fare out of one study after another convincingly demonstrating that the traditionally distinctive marks of the human (first it was possession of a soul, then 'reason,' then tool use, then tool making, then language, then the production of linguistic novelty, and so on) flourish quite reliably beyond the species barrier" (2). Human exceptionalism, the notion that we as a species are utterly or essentially different from all other life on the planet, has been proven false time and time again.

My approach strives toward an ecosystemic understanding of interrelationality, informed by Barry Commoner's first law of ecology: "Everything is connected to everything else." ${ }^{4}$ In short, all species, all creatures, exist in relation to and in the context of others. To consider any in isolation is to misunderstand how life works on this planet. Consider, for example, human flora or microbiota, the microorganisms that live on and in the human body at all times. There are, under normal circumstances, more bacterial cells on and in our bodies than there are human cells (Dethlefsen et al.). We are literally crawling and swimming with nonhuman life, hundreds if not thousands of species of it. Moreover, the bacteria in our digestive tracts (the vast majority of our nonhuman cells) $)^{5}$ allow us to process food, the nutrients from which we would be unable to absorb without them. It is not merely that we are what we eat; we are also the other beings that allow us to absorb what we eat. And they are us.

The old adage has it that no man is an island. Gendered coding notwithstanding, this has traditionally been taken to mean that people are always connected to other people. Ecology tells us that people (like all other species) are always connected to other species. The story of human flora tells us that we are actually composed of other currently living creatures. Human life cannot be understood outside our physical connections to other life. These connections can sometimes be defined as cooperative, sometimes as symbiotic, sometimes as confrontational or predatory. The fact that some of these connections are agonistic does not make them any less connections. In other words, I am not arguing that we exist in a global cooperative, merely a community in which we have certain responsibilities. We are members of complex interrelationalities that cross species lines. We are, whether we want to be or not, deeply 
and inexorably bound to these complex liquid communities that exist between people as they exist within all ecosystems. Moreover, as we are in fact comprised of multiple other species, the distinction between the human and nature is further confounded.

At this point, the term "nature" has been fairly well documented as a problematic signifier. Indeed, several other ecocritics have questioned the value of this term. For example, in "Cultivating the American Garden," Frederick Turner challenges the assertion that humans and the nonhuman are made of different stuff. He writes, "Nature, according to science, is as much 'in here' as it is 'out there" (42). Gary Snyder moves to include religious thought to Turner's evocation of science. In "The Etiquette of Freedom," he writes, "Science and some sorts of mysticism rightly propose that everything is natural" (8). Indeed, it is difficult for any philosophy that acknowledges humans as biological entities to figure humans (or by extrapolation, human creations) as not natural. One wonders how our creations are any less natural than a bird's nest, a beaver's dam, or a crow's crafting a tool to reach food.

I theorize pollution and waste within these novels as representative of a need to recognize human communities in a broad sense. That is, the authors I examine use waste to show our connections to the physical world in which we live. In this respect, I am deeply indebted, as are so many ecocritics, to Aldo Leopold's construction of community in his oftquoted concept of the land ethic. In his foundational text, Sand County Almanac, Leopold asserts, "The land ethic simply enlarges the boundaries of the community to include soils, waters, plants, and animals; or collectively: the land" (239). He continues, "In short, a land ethic changes the role of Homo sapiens from conqueror of the land-community to plain member and citizen of it" (240). Leopold's straightforward but nonetheless powerful assertion moves from a hierarchical relationship between humans and the other-than-human to a recognition of ecological community (although his term "citizenship" denotes a particular kind of community that is somewhat more specific than my conception). Building off of this idea and ideal of community, I identify a common theme in this study's urban-set novels-authored by Octavia Butler, Alejandro Morales, Louise Erdrich (Ojibwa), Karen Tei Yamashita, and Gerald Vizenor (Anishinaabe). In each of these works, the reclamation 
of waste objects and waste spaces serves as a necessary parallel to the reclamation of cast-off individuals and communities. In reasserting the importance of marginalized groups, these authors draw on parallels to the nonhuman - to other animals, plants, and landscapes that have been cast as waste or wastelands, beyond reclamation or outside human (or preferred human) habitation. ${ }^{6}$ These authors proceed to query pollution from a standpoint of miscegenation discourse to show that the tropes of purity, upon which both of these concepts (pollution and miscegenation) rely, fail in the face of the liquidity and permeability of human selves. The need for the recognition of this liquidity and permeability is the central conclusion of Positive Pollutions and Cultural Toxins.

Rather than pollution, I prefer an emphasis on toxicity. ${ }^{7}$ In this regard I am indebted, of course, to Lawrence Buell, who describes toxic discourse as a new focus of environmentalism that moves away from traditions of nature writing and preservation toward one of environmental justice, dealing with toxifying practices and events such as "Love Canal, Three Mile Island, Bhopal, Chernobyl, and the Exxon Valdez" (642), though he traces the dawn of contemporary toxic discourse to the 1962 release of Rachel Carson's Silent Spring. His essay, apart from being an excellent source detailing the "anatomy and genealogy" of environmental justice and the pastoral, "challenges traditional understandings of what counts as an environmentalist movement or ethos" (639) in order to underscore "the point that environmentalism must make concerns for human and social health more central and salient than it traditionally has if it is to thrive, perhaps even to survive" $(639-40)$. Buell calls for a move, one he later identifies as second wave ecocriticism, away from the bucolic nature of Thoreau and Muir and toward the concerns of contemporary marginalized communities. ${ }^{8}$

Building on Buell's ideas, I devote attention to toxicity rather than pollution or contamination for a variety of reasons. ${ }^{9}$ My primary aim is to challenge the seeming divide between first and second wave ecocriticism, to show that any constructions that divide the human from the nonhuman cannot stand. To that end, I focus on the root meanings behind terms that have come to foreground much of environmentalist and ecocritical discourse. I eschew terms like "pollute" or "contaminate" because both imply former states of purity, moments during which spaces 
and places (and in other discourses, bodies, cultures, religions, and languages) were untouched, inviolate, untrammeled, or unadulterated. To pollute is, "to make morally impure; to violate the purity or sanctity of; to profane or desecrate; to render ceremonially unclean (obs.). Now also: to corrupt, sully" (OED). To contaminate: "to render impure by contact or mixture; to corrupt, defile, pollute, sully, taint, infect” (OED). Both of these verbs (and their corresponding nominal forms, pollution and contamination) imply that the afflicted was once pure and is now impure. Contamination's focus on touching connotes dirty human hands groping at some previously untouched wholesomeness. Both indicate a separation between the human or the human made and everything else, a binary that I assert proves indefensible.

On the other hand, toxicity means simply "the degree to which a substance is poisonous." If we follow the chain of signification one step further we learn that poisonous denotes, "causing or capable of causing death or illness if taken into the body." Looking at toxicity, to me, speaks to the point at which a given ecosystem and the other ecosystems downwind and downstream (which eventually, of course, are all ecosystems), become biologically unlivable for the species within them. ${ }^{10}$ Nonetheless, the concept of toxicity should be wielded carefully within environmental studies. Ecocritic David Garrard cites chemist William H. Baarschers as "highly critical of environmentalist 'hysteria' surrounding the presence in the environment of chemicals far below levels of observable toxicity" (II). Baarschers, in his book Eco-facts and Eco-fiction, calls for a pragmatic environmental discourse, one that abandons impossible ideals of zero-level contamination for realizable goals of minimized toxicity. It would be hard to find a space that does not contain some toxins, whether biological waste, "persistent organic pollutants" (POPS), or what have you. That does not necessarily make them unlivable or even threats to the life within them. Still, herein lies the danger of Baarschers's argument: at what level can we unequivocally assert that a space has become toxic? His definitions follow a scientific method, one of repeatability and certainty. One problem with such an approach when dealing with toxicity is that by the time we have reached a level of certainty as to cause and effect, a number of those toxified bodies have perished or become moribund. Another problem arises from the difficulty of tracing a single 
cause to toxic effects, when we might better understand a cumulative effect from a number of toxic agents. ${ }^{11}$

Several critics work to address this problematic of either proving causal relationships between toxic exposure and its effects or recognizing strong correlations between them. David Naguib Pellow demonstrates, "Ecological risks are deeply embedded in society and are ubiquitous and extremely harmful, yet frequently difficult to measure" (24). Similarly, Lois Gibbs expands, "The obstacles facing modern environmental health investigators are ... complex. First, there is the lack of scientific understanding of the body's interaction with chemicals; second, there is the lack of studies that provide clear evidence linking cause and effect in humans, for most of the chemicals in use; and third, there is the enormous financial interest of multibillion-dollar corporations that want to avoid identifying any link between their chemicals and products and adverse health effects." (ix) ${ }^{12}$ In short, the cards are stacked in many ways against the victims of toxification - both by the sluggishness of scientific proof and the economic and political structures that favor business interests over bodily health (especially of the communities frequently targeted for toxic exposure). Julie Sze, in her reading of Yamashita's Tropic of Orange, asserts that her "goal is to posit the emergence of an environmental justice framework that is not constrained to a particular method or discipline or the paralyzing need to statistically 'prove' environmental racism" (30). Rather than restrict ourselves to the slow-to-develop and difficult-to-prove scientific method, we can recognize the veracity of narratives of environmental justice.

I offer the term positive pollutions to represent a multitude of transgressive mixings that might be historically coded as negative, but which are demonstrated to be anything but. The positive pollutions within this book take numerous forms, overturning ideals of cultural, linguistic, ecological, racial, ethnic, sexual, and religious purities in favor of embracing liquid mixtures and ideals of broad communities and responsibilities. Rather than assuming an impossible preexisting purity, these liquid conceptions understand the value-indeed the imperative-of understanding that we represent a single but dynamic collectivity. They are not dangerous; or if they are, they are only dangerous to those ideologies that seek to segregate, to contain, in the hopes of physically, socially, 
politically, and economically marginalizing. In utilizing the term "positive pollutions," I seek to invert the seemingly inherently negative appellation of the verb "pollute" rather than to uphold pollution as a particularly useful trope. Rather, each of the novels I study here reclaims bodies and spaces that have been seen, crafted, racialized, gendered, and sexualized as polluted and/or polluting. However, this is not to say that all muddying of boundaries, let alone toxification, is positive. Indeed, we can think of countless examples of what are currently deemed ecological pollution that I would absolutely assert are negative, destructive, unjust, or just plain wrong. Moreover, these unjust interpenetrations or seepings need not reach the full scale of toxicity. My notions of community suppose an attempt to minimize our destructive impact on the rest of the biosphere. The danger with this ideal, of course, comes in determining what, exactly, "destructive impact" means. I hope to be suggestive here rather than prescriptive, and I recognize the precautionary principle as one helpful model. This principle asserts, "When an activity raises threats of harm to human health or the environment, precautionary measures should be taken even if some cause and effect relationships are not fully established scientifically. In this context the proponent of an activity, rather than the public, should bear the burden of proof. The process of applying the precautionary principle must be open, informed and democratic and must include potentially affected parties. It must also involve an examination of the full range of alternatives, including no action" (Science and Environmental Health Network). Rather than potential victims of toxicity shouldering the burden of proof, we can focus our environmental governance and ethics on ensuring responsible activity.

Along with analysis of ecological or material toxicity, I propose that we think of racism and other oppressive forces as what I term cultural toxins. Rather than miscegenation's ideal of a pure body politic —or (as just one example) recent, thinly veiled racism decrying mostly Latina/o immigrants for culturally and linguistically polluting U.S. culture-cultural toxicity refers to a society becoming literally unlivable for its inhabitants. The continuing violent threats of racism, misogyny, and homophobia are examples of cultural toxicity within the United States (though certainly not exclusively) today. Histories of ethnic cleansing and genocide

\section{Introduction}


represent cultural toxicity taken to an extreme (albeit a predictable one). Any number of colonialisms, racist wars, or wars justified in racialized terms fit the bill as well, as does environmental racism. Indeed, many of the aforementioned ideologies of purity throughout history create toxic environments for marginalized communities. Throughout this book, I examine textual representations challenging such quests for purity under the rubric of cultural toxins.

While I am challenging the theoretical utility of ideas like pollution or, say, wilderness spaces, I am not suggesting that these rhetorical tropes should be eliminated, particularly as they relate to our political or activist discourse. Within the current cultural moment that gives at least lip service to green living, environmentalism has tremendous opportunities to make political gains, inroads, and allies. These are fundamentally important material concerns and ought not to be hamstrung by an allegiance to theoretically sound terminology. Nonetheless, I think it behooves those of us within ecocriticism and environmental studies to be self-aware that such terms are being wielded tactically and that we disallow a certain level of discourse with their use. It could be argued that this tactical wielding of "pollution" as a term is tantamount to hypocrisy. I find such absolutism (another version of purity) in terms of political struggles somewhat curious, even dangerous, as I am quite certain that organizations and individuals responsible for toxifying our ecosystems are not nearly as concerned or burdened with a morality of absolute truth. In short, I recognize politics and theoretical/critical work as deeply intertwined and informing one another, but as existing within rhetorical traditions that differ in the immediacy of their ends.

Likewise, as the reader has no doubt noticed, I make use of the term "liquid" throughout this text. I choose the term "liquid" rather than "fluid" because of the latter's etymological connection to flow (French fluide, Latin fluid-us, fluĕre to flow), which seems to me to connote directionality. I use liquidity instead to refer to "a material substance in that condition (familiar as the normal condition of water, oil, alcohol, etc.) in which its particles move freely over each other (so that its masses have no determinate shape)" (OED). Liquids pass over and through one another, blending and separating depending on their properties and their temporary conditions (temperature, for example). Their motion is 
difficult to predict, often vectorless; but within the course of their motions, they invariably take on properties they did not possess before. As Stephen Hong Sohn explains, "As the state of matter between solid and gas, the liquid inhabits an interesting state of dynamic equilibrium that at once cannot be fully grasped, but yet has a texture and a 'feeling.." ${ }^{13}$ I imagine this liquidity representing the permeability of everything. All bodies, cultures, and processes are not only permeable, but permeated, affected by the other bodies, cultures, and processes that flow or seep on, over, by, and through them. Such liquidity challenges claims of purity as not only theoretically but practically difficult to defend. Such a lack, or rather absence, of purity need not be lamented or maligned, however. Instead, the fact that even the most solid matter maintains a liquid quality reinforces the interconnection and community that I advocate here. ${ }^{14}$

Much of the hegemonic discourse surrounding the United States' idealistic and nostalgic views of itself imagines rural and small-town (later suburban) clean living. ${ }^{15} \mathrm{~A}$ recent Gop vice presidential candidate, in 2008, called small towns "the real America" and "pro-American areas of this great nation." The implication, of course, is that cities are both not really America (by which I suspect was meant the United States) and anti-American. The discursive tradition out of which such comments grow draws a distinction between the dirty, dystopic urban and the pristine, utopian natural. ${ }^{16}$ Cities are often portrayed as places to be fled, metropolitan wildernesses that offer nothing more than the maladies of overcrowding, poverty, crime, and pollution. More often than not, these areas are coded as black/brown and white, respectively (though representations of rurality in texts by authors of color as ideal, idyllic, or, at least, preferable to urbanity certainly complicate-or troublingly participate in-such a generalization). The texts I examine dismantle the human/nature dichotomy, detailing and imagining African American, Chicana/o, Native American, and Asian American urban communities in which humans are recognized very much as natural, corporeal, and material systems. ${ }^{17}$ Moreover, these novels utilize the physical signs of human corporeality like garbage and sewage to refigure cities as natural. All the texts I examine overtly address environmentalist issues (particularly toxic air and aquifers as well as waste dumping and containment). However, each text also demonstrates the parallels between hierarchical 
views of cultures and those of nature/culture and/or humans/other species. Each novel shows urban spaces as indecipherable or inseparable from the other-than-human or the natural-though they do this to varying degrees and with varying levels of consistency.

It is not a coincidence that urban centers (which, as Andrew Light points out, have come to be seen as the new, built wilderness that ought to be fled for the safety of the ruralized suburb) are also generally the most racially diverse spaces in the United States. Eric Avila notes that Ronald Reagan rose to power in California, and eventually in the United States as a whole, by pandering to and bolstering suburban white voters' fears of people of color in the cities (9I). Similarly, James Kyung-Jin Lee states, "Nowhere does the shattering of multiculturalism's dream become more apparent than in U.S. cities during the 'belle epoque' of the Reagan era" (xiv). He notes that under the twelve years of the Reagan and Bush administrations, "Cities and their residents suffered economic, political, and cultural hemorrhage so great that it constituted nothing less than a great urban crisis of terminal proportions" (xiv). These antiurban ideologies are among the fundamental tenets of neoconservativism. It has sown and continues to cater to white fears of people of color in the cities. Unfortunately, middle-class environmentalism has tended to parallel this antiurbanism. While the suburbs embody material white flight, it is not a stretch to aver that environmentalism is a form of political white flight. Rather than confront the ecological injustices of the cities, many environmentalists are happy to write off urban spaces and their denizens (human and nonhuman alike) as beyond help. All too often, environmentalism's arm of cultural criticism, ecocriticism, becomes a similar form of academic white flight. ${ }^{18}$

In her classic investigation of purity and pollution, Mary Douglas notes that creating differences such as within/without, male/female, and clean/dirty allows a semblance of order on life but that this binaryconstructing compulsion disappears in great religions. While contemporary readers are troubled by Douglas's universalizing claims as well as her distinction between primitive and great religions, her more basic premise- the source of her lasting contributions to cultural studiescertainly holds true. She notes, for example, "These danger-beliefs are as much threats which one man uses to coerce another as dangers which 
he himself fears to incur by his own lapses from righteousness" (3). Distinctions between the pure and the polluted serve an administrative purpose, governing behavior. But Douglas shows that they do more; she continues, "Ideas about separating, purifying, demarcating and punishing transgressions have as their main function to impose system on an inherently untidy experience. It is only by exaggerating the difference between within and without, above and below, male and female, with and against, that a semblance of order is created" (4). People utilize these binary distinctions (exaggerating them) to make sense of a world that is messy, vague, and murky. Throughout this work, I strive to question the us/them binary that becomes buttressed by notions of purity and pollution and constructed along species, racial, ethnic, and cultural lines. While these binaries mark an attempt to define where and how we can close our ranks, they limit our abilities to create, maintain, and recognize our broad, but very real, lived material communities. Nonetheless, minoritized communities (like all human communities) will sometimes circle the wagons in terms of identity. I am not attempting to elide cultural differences or striving for a color-blind society. Rather, I find it generally positive to understand the permeability of self and culture to recognize rather than deny or condemn ethnic adaptation. Instead of static ideas and ideals of cultural conservatism, we can understand that cultural changes need not threaten, reduce, or water down ethnic, racial, or national identifications. The novels I study throughout this text present communities comprised, as communities always are, of multiple ebbing and flowing liquid identities, interpenetrated culturally as well as spatially and temporally. Indeed, these texts move to show that racial differentiation need not serve as the sole criterion used to mark ethnic belonging. Nor do I intend in any way to downplay the material importance of racial categorizations (and the physical threats that arise from the cultural toxin of racism). People continue to be read and coded racially, especially by phenotype.

The tendency to create divisions between humans and the rest of the world very closely parallels the divisions between groups of people. Some ecologically minded critics and scholars have marked this correlation. Pellow, for example, asserts, "The basic functions of industrialized societies (primarily in the global North) involve the production of both 
intense ecological harm and extensive social hierarchies (primarily by race, class, gender, and nation)" (5). Jeffrey Myers similarly argues, "The ethnocentric outlook that constructed 'whiteness' over and against the alterity of other racial categories is the same perspective that constructed the anthropocentric paradigm at the root of environmental destruction" (5). Eric Katz focuses on "imperialism-and all that it represents concerning power, force, and domination-as a model or metaphor for understanding the human relationship with nature" ( $\left(6_{4}\right)$. Finally, Jake Kosek demonstrates, "Discourses of purity placed diluted racial subjects and degraded landscapes into the same 'grid of intelligibility,' wherein understanding of and fears surrounding race at the turn of the twentieth century became the raw substance out of which wilderness as an idea and a landscape was forged" (129). Each of these scholars understands the direct relationship, whether causal or otherwise, between racialized and anthropocentric hierarchies as well as the social and ecological dangers and cruelties they lead to.

I place my examination of waste as part and parcel of this challenging of the pure and the polluted. I argue that, although we tend to think of garbage as inherently offensive: toxic, smelly, dangerous, and useless, in short, abject, these conventional judgments place a negative value on a simple byproduct of existence; all animals produce waste. I refigure waste and garbage by showing how these urban-set novels illustrate that we cannot partition ourselves from the waste we produce. This inclusive worldview emphasizes communal responsibility in regard to the things and the people we cast off and refigures waste and pollution as tropes with potentially positive attributes: cast-off places, objects, and people can be regenerative sites of community building.

In studying these recent texts, Positive Pollutions and Cultural Toxins intends to help continue ecocriticism's and environmentalism's evolutions. One of its goals is to maintain and foster discourses of environmental justice and studies of environmental racism. Civil rights activist Benjamin Chavis describes the connection between environmental and racialized social issues: "Racial discrimination is the deliberate targeting of communities of color for toxic waste disposal and the siting of polluting industries. It is racial discrimination in the official sanctioning of the life-threatening presence of poisons and pollutants in communities 
of color. And it is racial discrimination in the history of excluding people of color from the mainstream environmental groups, decision making boards, commissions, and regulatory bodies" (3). Environmental justice responds to the fact that, as Jace Weaver notes, "Those involved in the environmental movement are overwhelmingly White" ("Introduction" xv). Similarly, Joni Adamson, a central figure in the literary study of environmental justice, describes its goal: "to redress the disproportionate incidence of environmental contamination in communities of the poor and/or communities of color, to secure for those affected the right to live unthreatened by the risks posed by environmental degradation and contamination, and to afford equal access to natural resources that sustain life and culture" (4).

Two events are most commonly cited as the dawn of the environmental justice movement: protests surrounding Love Canal in upstate New York (1978) and the Warren County Рсв Landfill in North Carolina (I982). ${ }^{19}$ Local residents in Love Canal pointed to higher-than-normal rates of birth defects, miscarriages, and congenital diseases stemming from toxic waste seeping into their aquifer. Warren County residents charged federal, state, and local governments with choosing their area for dumping because they housed a rural, predominantly African American community. Another oft-cited example of this type of waste targeting is nuclear mining, testing, and dumping on American Indian lands in the desert southwest. ${ }^{20}$

While a number of ecocritics have complicated the division between humans and the nonhuman, ecocriticism itself fails to give sufficient attention to narratives of cities. A few texts have begun to correct this oversight, however. Collections like Terrell F. Dixon's City Wilds: Essays and Stories about Urban Nature and Michael Bennett and David W. Teague's The Nature of Cities: Ecocriticism and Urban Environments are two examples. Bennett and Teague lament, "Ecocriticism has come to be associated with a body of work devoted to nature writing, American pastoralism, and literary ecology" (3). Likewise, Dixon points out that "Even as interest in environmental literature has grown over the last four decades, urban nature has figured most often as an intriguing, if mostly marginal oxymoron" (xi). Both of these texts address ecocriticism's myopia in terms of urban spaces. Moreover, basic understand-

I4 Introduction 
ings of interconnection should imply the importance of cities to a global, local, regional, and bioregional understanding of space and place. As McGranahan et al. note, "The fact that cities have large ecological 'footprints' makes them more, not less, important" to ecologically minded studies (8). Nonetheless, Dixon's focus remains on the natural as something distinct from the human, something that interacts all the time with humans but that is still separate. According to this point of view, there may be nature in cities, but the cities themselves are not natural. My interest is not in showing that there are nonhuman elements in cities; of course there are. Trees, plants, birds, insects, rodents, all these live in cities; many have evolved in tandem with human beings in centralized, high-density urban settings. Along with that coevolution is the simple fact that we are natural. So are the things we make.

If ecocriticism "itself has been slow to survey the terrain of urban environments," as Bennett and Teague assert, it was, in its earliest stages, equally slow in surveying work from authors of diverse ethnic and cultural backgrounds (3). Myers lays out a road map of the development of ecocriticism along these lines in Converging Stories: Race, Ecology, and Environmental Justice in American Literature (6-7). He points out that the bulk of ecocriticism dealing overtly with issues of race have focused on American Indian writers and, to a lesser degree, African American authors. Until quite recently, and largely after the inception of this project, very little work had been done with Asian American- or Latina/oauthored texts, despite the fact that a number of them serve as excellent subjects. However, in recent years this dearth of diversity has undergone a rapid and welcome change. Lawrence Buell and Ursula K. Heise represent two of the very impressive scholars to address issues of race and ethnicity in ecocriticism. Other sources include Alison Deming and Lauret Savoy's The Colors of Nature: Culture, Identity, and the Natural World (2002), Joni Adamson's American Indian Literature, Environmental Justice, and Ecocriticism: The Middle Place (200I), Lee Schweninger's Listening to the Land: Native American Literary Responses to Landscape (2008), Tom Lynch's Xerophilia: Ecocritical Explorations in Southwestern Literature (2008), Lindsey Claire Smith's Indians, Environment, and Identity on the Borders of American Literature: From Faulkner and Morrison to Walker and Silko (2008), Paul Outka's Race and Nature from 
Transcendentalism to the Harlem Renaissance (2008), and Ian Finseth's Shades of Green: Visions of Nature in the Literature of American Slavery, 1770-1860 (2009). The publication dates of these texts illustrate just how contemporary these changes to the field are. And these represent only the book-length texts devoted to this socially engaged ecocriticism. ${ }^{21}$

\section{CRITICAL AND THEORETICAL ANTECEDENTS}

Throughout this text, I draw on urban cultural studies texts including those by Eric Avila, Edward Soja, James Kyung-Jin Lee, Mike Davis, Raúl Villa, and Josh Sides..$^{22}$ However, the single most influential scholar to my studies of modern urban life is Michel de Certeau, especially his text The Practice of Everyday Life. Certeau's work reexamines urban identity, which is so often painted as a form of victimization at the hands of urban administrators, in order to show the individual and communal power that denizens of cities actually possess. Certeau specifically examines issues of waste and pollution as they relate to abnormality, deviance, and illness. Because his work is so influential to my own, I dedicate some time to my explication of his thesis and the terms he employs. ${ }^{23}$ Certeau challenges administrative panoptic mandates and serves as a corrective for overly deterministic notions of ideological indoctrination-emphasizing instead the agency, tactical navigation, and adaptability of marginalized and disenfranchised individuals and communities. His work illuminates cultural and personal evolutions, emphasizing survival rather than what Gerald Vizenor calls "victimry," the adopting and internalization of the role of victim by marginalized populations.

My correlation between marginalized communities and images of pollution parallels Certeau, who argues that planners and administrators of cities seek to codify the lives of the people who live in the city with the aim of maximizing order and that "rational organization must thus repress all the physical, mental and political pollutions that would compromise it" (94, emphasis mine). The city's agency_or the agency of those who attempt to control, organize, and plan the city-seeks to override the agency of the inhabitants of that city as an operational concept. Rather, "Everyday life invents itself by poaching in countless ways on the property of others" (xii, emphasis original). Poaching, a legal term, 
refers to human ownership of the nonhuman (both in terms of land and the species on that land); the crime combines trespassing with illegally taking game. Poaching represents an encroachment on the rights of a wealthy, empowered, or administrative body by someone looking to fulfill the most basic of animal needs (the need for food). More broadly for Certeau, poaching implies a tactical agency that works outside the rules but is most efficient when it avoids detection (rather than direct confrontation).$^{24}$ Certeau continues with his trope of poachers qua pollution: "There is a rejection of everything that is not capable of being dealt with [via differentiation and redistribution] and so constitutes the 'waste products' of a functionalist administration (abnormality, deviance, illness, death, etc.)" (94). Pollution and waste products within this mode are defined simply as those people and things that do not fit the mold of the organizationalist urban planners.

Certeau offers the idea of the tactic as a counternarrative to administrative attempts to control. He argues that despite the best efforts of the administrators, "the city is left prey to contradictory movements that counter-balance and combine themselves outside the reach of panoptic power" (95). He continues describing a tactic as "a calculus which cannot count on a 'proper' (a spatial or institutional localization), nor thus on a borderline distinguishing the other as a visible totality. The place of a tactic belongs to the other. A tactic insinuates itself into the other's place" (xix). Moreover, for Certeau, "The 'proper' is a victory of space over time. On the contrary, because it does not have a place, a tactic depends on time-it is always on the watch for opportunities that must be seized 'on the wing.' Whatever it wins, it does not keep" (xix). Ultimately, essentialism rests on the proper, on the strategic, and on the place. Fixed essentialisms (as Douglas notes) come from places of power and attempt to control existence by naming and describing something (and the borders, boundaries, and frontiers delimiting that something from everything else).

Throughout Positive Pollutions and Cultural Toxins, I draw on Certeau's terminology clarifying the differences between strategy and tactic and between space and place. He writes, "I shall make a distinction between space (espace) and place (lieu) that delimits a field. A place (lieu) is the order (of whatever kind) in accord with which elements are distributed 
in relationships of coexistence. It thus excludes the possibility of two things being in the same location (place). The law of the 'proper' rules in the place. ... A space exists when one takes into consideration vectors of direction, velocities, and time variables. Thus space is composed of intersections of mobile elements" (II7). Place equates to structure, stasis, strategy, and a conceived but unlived, unlivable theory and panoptic mandate. On the other hand, space corresponds to movement, intersection, subversion, tactic, and, in short, the real way that humans experience and shape the shifting locations in which they live. Place is the illusion of solidity; space is the recognition of liquidity. We must, furthermore, relate the movement and interrelationality of tactical and space-based existence to the tenets of ecology, which likewise recognize the fundamental truth that living bodies never exist in isolation or stasis-whether that stasis is spatial or temporal. We would do better to understand bodies and spaces as processes rather than as distinct entities. These are liquid mixtures of elements, always on their ways toward becoming something else. Moreover, the concepts of time and space are foundational for one another: spaces are always in flux, shaped by our presence and motion, and always in motion themselves. ${ }^{25}$ The novels I examine throughout this project all reflect Certeau's notions of the urban dweller as tactical agent and administrative pollutant while connecting humanity to the rest of the biosphere. ${ }^{26}$

Certainly, these narratives of polluted urban spaces and bodies have not materialized ex nihilo in the contemporary moment. Tales of environmental apocalypse bloomed in the I96os; Rachel Carson's Silent Spring and Paul Ehrlich's The Population Bomb are two examples of what Mike Davis calls texts of ecocatastrophe (3I8). Davis asserts, "Like the inevitability of nuclear war, the biological unsustainability of the giant city is now firmly lodged in contemporary doom consciousness" (3I8). He continues, "It is not surprising, then, that the climax of the postwar boom in the mid-Ig6os saw the parallel emergence of fictional and nonfictional accounts of imminent ecological collapse, frequently in tandem with Malthusian fears about too many poor people of color" (318). Fears of the urban center, and the imaginative death drive of cities, stem in no small part from classist and racist fears. Avila adds other social elements, including fears of excessive sexuality, as a part of white flight 
from city cores. He notes that postwar suburbanization, especially in Los Angeles, stemmed from "an emergent sociospatial order that promised a respite from the well-known dangers and inconveniences of the modern city: congestion, crime, pollution, anonymity, promiscuity, and diversity" (xv). ${ }^{27}$

Finally, throughout this project, I build upon foundations from religious studies and Native American studies scholar Jace Weaver (Cherokee), who emphasizes inclusive and permeable communities that encompass our physical environments and the animals therein. Weaver's concept of communitism in particular has influenced my approach tremendously. This neologism is "formed by a combination of the words 'community' and 'activism'" (That the People Might Live xiii). He continues, "Literature is communitist to the extent that it has a proactive commitment to Native community, including what I term the 'wider community' of Creation itself" (xiii). Although Weaver's approach is one of Native American studies-and later, American Indian nationalismwe can apply it more broadly. Because Native American communities are members of a global (or perhaps more expansively, cosmic) community, encompassed in the wider community of creation itself, communitism stretches to cover that wider community. It is not exclusively Indian. The community of communitism is comprised of all humanity as a part of everything, including all elements of the other-than-human. In this recognition of broad communities, we are charged with recognizing the self in the other, to come to terms with the fact that destructive acts are not only cast outward but also always inward. ${ }^{28}$ I argue that literary and ethnic studies need to continue to build toward examining these relational identities formed by and with our ecological communities.

\section{ORGANIZATION OF THE BOOK}

Positive Pollutions and Cultural Toxins explores the conjunction of, and the frictions between, studies of twentieth-century U.S. ethnic literatures, urban studies, and ecocriticism and works to refigure the above portrayals of urban spaces. I have selected the novels I study here for a few reasons. First, each of these texts places itself in the broader conversations of contemporary literary studies. Butler's novels represent the neo-slave 
narrative, which, under the umbrella of African diasporic texts, occupies a central position within African American literary studies; Morales's text grapples with the controlling ideologies of Chicana/o studies, the pervasiveness (and masculinist tendencies) of Chicano nationalism in the face of a postnationalist impulse throughout much of ethnic and postcolonial studies; similarly, Erdrich's and Vizenor's novels tackle issues of tribal nationalism, the single most hotly debated issue in Native American studies today, along with the ever-present tensions around mixed-blood and urban Indian identities; Yamashita's text embodies the transnationalism that has come to dominate conversations within but also far beyond Asian American studies. Of course, my approach of dividing the chapters according to racialized categories has the danger of upholding the divisions between these communities. That upholding is not my intention. However, I also realize that ignoring or eliding the communities on which these texts focus is not a preferable option.

Instead, each of these texts understands that the racialized community represented within its pages can never properly be understood in isolation. Every one of these novels represents its primary community as part of a larger, multiethnic one, and in this sense these texts prefigure a growing element within ethnic studies fields as they move beyond the isolating nationalisms that have bound them in order to recognize broad communities (which herein are both interspecies and interethnic). While these novels are all concerned with how we act locally, they are nonetheless all thinking globally, working in transnational frameworks that more accurately represent the world as it is than do many other accounts. Each text, while U.S. in its origin, nonetheless understands the nation as a permeated space-one which generates certain toxic hierarchies while asserting its purity only to contravert that purity in terms of movements of bodies (of many species) and commodities (including those same bodies).

These chapters serve as connected essays demonstrating the wielding of the themes I identify and theorize throughout this introduction. I have not attempted to organize them as a progressive linearity, an approach that would counter the liquid permeations I privilege. All these texts, I argue, ultimately embrace cities as natural outgrowths of human collective behaviors and as spaces of healing and reclamation. At the 
same time, they draw attention to the cultural and ecological toxins faced by urban minoritized enclaves. Rather than fleeing these sites, however, or giving up on them as lost causes, the texts suggest methods by which human societies can recognize our communal responsibilities within cityscapes in order to prevent and reverse ecological destruction.

My first chapter, "'Failing Economies and Tortured Ecologies," examines the toxic dystopic vision of Los Angeles within Butler's Parable of the Sower (1993) and its sequel Parable of the Talents (1998). Parable of the Sower offers an optimistic pastoral conclusion for its multiethnic cast of characters. But the failure of Parable of the Sower's pastoral dream in Parable of the Talents shows that flight from urban blight, whether couched in terms of suburban segregation or more recent nonwhite middle-class departures from city centers, is short-sighted and doomed to failure. Instead, these novels illustrate the impossibility of fencing oneself off from socioecological ills. I place my reading alongside recent scholarship examining Southern California's history of racialized suburban exclusion and isolation, especially as pertain to African American bodies and communities, to reinforce this assertion.

In chapter 2, "Toxic Metropolis," I investigate the roles of toxicity and positive pollution in Morales's The Rag Doll Plagues (1992) and argue that this novel's theme of the pepenador (or rummager) exemplifies a recognition that humanity cannot be differentiated from the waste it produces. ${ }^{29}$ This text shows how urban communities especially reclaim cast-off objects and individuals to show their inherent value. In so doing, Morales figures a community between humans and other animals within a Mexica religious framework that has gone unexamined by critics. Interethnic communities also abound in this novel as people of diverse descents commingle to create an idealized hybrid within the occasionally toxic cityscapes of Mexico City and Los Angeles. These urban spaces themselves, furthermore, require attention that has not been undertaken by critics of this novel. To that end, I include the environmental histories-especially in terms of their parallels —of these two cities, looking at how they became among the most toxic regions in the Western Hemisphere.

Chapter 3, "Ridding the World of Waste," illustrates that, in The Antelope Wife (1998), Louise Erdrich (Ojibwa) creates a recurrent theme 
of garbage in an urban Native community (portrayed as a broad and diverse spectrum of mixed-blood identities), which is built on top of that garbage. I argue that Erdrich's ambivalent portrayal of garbage reflects issues of environmental justice that Native people across the continent continually face, such as legal and illegal dumping on tribal land. Erdrich's pairing of mixed-bloods with trash reclamation counters the ever-present but historically and theoretically flawed suppositions of and calls for Native racial and cultural purity. This novel examines relocation, set in a locus the Bureau of Indian Affairs Relocation Program, Minneapolis, Minnesota. This program, which operated from the I950s through the I970s, fostered Native people to move from rural and tribal lands to urban centers in order to encourage assimilation and industrial vocational training. Revolving around a discourse of balance, Erdrich's text vilifies selfishness from an Ojibwa perspective by invoking the image of the Windigo, a monster of greed that can overcome people who lose their connections and sense of responsibility to their communities.

In chapter 4, “An Eerie Liquid Elasticity,” I discuss Yamashita's Tropic of Orange (1997) to show the novel's understanding of human identities, cultures, language, and space as always in flux. Yamashita wields Southern California's seismic activity, location along the Pacific Rim and Ring of Fire, shared border with (and perhaps more importantly, historical location in) Mexico, and role as global center as a site for recognizing fluid natures of a humanity that cannot properly understand itself within any manner of static construction. The text refuses monoracial, monocultural, and anthropocentric worldviews and instead privileges an understanding of multiethnic communities and individuals as sites of regeneration and hope, while also understanding human connections to our ecological communities. Furthermore, along with the insistence within the text that space and place are truly fluid, the reader also encounters a recognition that time (as bound to space in time and space) cannot properly be understood as linear (let alone as a progressive march) but rather is experienced as a singularity in which past, present, and future constantly ebb and flow, rise and submerge, and exist simultaneously.

Finally, in chapter 5, "'Outcasts and Dreamers in the Cities," I discuss Vizenor's Dead Voices: Natural Agonies in the New World (1992) to 
show the ways that people can come to form profound relationships to place even in sites of (in this case Native American) displacement and relocation. I argue that this text reflects a complete formation of an urban community in its reclamation of landfills and sewers as integral and religiously significant spaces that must not be ignored. The community within this novel is not only interethnic and interracial but also interspecies, as human ties to physical place and to plant and animal species are reinforced. I engage again with the history of the Relocation Program particularly in terms of Oakland as a marginalized space and in terms of stereotypes of urban Indians as isolated, lost, and degraded.

In short, my work examines what happens when we imagine our communities-or more to the point, recognize our communities-as being not just intrahuman but across species and even kingdom lines (in the Linnaean sense of the term). The novels I study illustrate and imagine these communities of liquidity and motion, of interpenetrations and interactions. I argue that they advocate broad understandings of community and the recognition that we are all responsible for what happens within those communities. Similarly, we are responsible for what we dump, what we excrete, what we leach into our ecosystems and, by extension and dispersion or diffusion, into the connected, local, and distant ecosystems of our planet. We might expect such environmentally engaged texts to ignore or vilify urban life and communities, but they do not. Instead, they reclaim urban spaces as natural and naturalized sites where interactions between the deeply and broadly interconnected human and nonhuman are the norm. Moreover, they emphasize the similarities between human behavior and that of other species. Finally, in taking back the urban wilderness as a vital locus for marginalized communities, they challenge mainstream environmentalism's and ecocriticism's existent if lessening white flight impulses. Cities become sites, not of total disaster, but of hope. The city and its inhabitants are not doomed; instead, they are, we are, the future. 